This item was submitted to Loughborough's Research Repository by the author.

Items in Figshare are protected by copyright, with all rights reserved, unless otherwise indicated.

\title{
A critical argument in favour of theoretical pluralism: project failure and the many and varied limitations of project management
}

PLEASE CITE THE PUBLISHED VERSION

http://dx.doi.org/10.1016/j.jproman.2013.08.005

\section{PUBLISHER}

(C) Elsevier, APM and IPMA

\section{VERSION}

AM (Accepted Manuscript)

\section{PUBLISHER STATEMENT}

This work is made available according to the conditions of the Creative Commons Attribution-NonCommercialNoDerivatives 4.0 International (CC BY-NC-ND 4.0) licence. Full details of this licence are available at: https://creativecommons.org/licenses/by-nc-nd/4.0/

\section{LICENCE}

CC BY-NC-ND 4.0

\section{REPOSITORY RECORD}

Sage, Daniel J., Andrew R.J. Dainty, and Naomi Brookes. 2019. "A Critical Argument in Favour of Theoretical Pluralism: Project Failure and the Many and Varied Limitations of Project Management”. figshare. https://hdl.handle.net/2134/25279. 


\title{
A critical argument in favour of theoretical pluralism:
}

project failure and the many and varied limitations of project management

\section{Word Count: 10,800 (including abstract and references)}

\begin{abstract}
In project management, failure is often assumed to be evidence of deficient management: a problem that can be overcome by better management. Drawing on qualitative research within UK construction projects we examine how four different theoretical approaches (positivism, structural Marxism, interpretivism and actor-network theory) all challenge this managerial assumption. Each theoretical perspective enables a specific analysis of empirical data that critiques the notion that project failures are easily, simply, or largely, associated with the failure of project management. In so doing, our pluralist analysis reveals the social and political contextualization of performance in project management. We thus conclude by proposing that practitioner and scholarly concerns with project failure (and success), can actively contribute to attempts to reflect upon various matters of political concern as developed within the Making Projects Critical community, and by extension Critical Management Studies. Thus, we propose greater interaction between critical and mainstream project research communities.
\end{abstract}


Keywords: Project failure, critical project studies, performativity, theoretical pluralism

\section{Introduction}

Failure is a persistent trauma within organizations, especially perhaps within project-based organizations (Lindahl and Rehn, 2007). Stories of "failed", or "failing" projects, abound in the media, from construction (London's Wembley Stadium), to aerospace (F-35 fighter,) and IT (UK NHS patient record system). Whilst project failures can and do result in lost share prices, or football matches, their effects can also include lost public funds, safety, homes, communities, health, and even life itself. While the "projectificaiton of society" (Lundin and Soderholm, 1998), and the proliferation of project management (PM), has been subject to mounting critical interrogation (Bresnen, 2007; Cicmil et al. 2009; Clegg and Courpasson, 2004; Hodgson, 2002; 2004; 2005; Hodgson and Cicmil, 2006; 2007a; 2007b; Lindgren and Packendorff, 2006, 2007; Styhre, 2006; Sage et al., 2010a), as reviews by both Söderlund (2011) and Turner et al., (2013) indicate, the phenomena of "project failure" (and "success") continues to be understood largely from within a narrowly functionalist-positive/managerial perspective (for some exceptions see Fincham, 2002; Lindahl and Rehn, 2007; Sage et al., 2013). 
Taking this tendency as our cue for critical analysis, in this paper we evaluate different theoretical approaches as means of contributing to the "Making Projects Critical" agenda of addressing managerial concerns with performativity without instrumentalizing knowledge to that intent (Hodgson and Cicimil, 2006). Our use of "performativity" here mirrors that of Fornier and Grey (2000) who explain how within management and organization disciplines knowledge and truth are mostly wedded to the pursuit of managerial efficiency and control. Our purpose here is to explain how the study of project failures can be a much more richly variegated enterprise. Specifically, we seek to engage readers interested in reflecting upon how the relationship between project failure and project management might be understood across different theoretical approaches. In so doing, we reverse the prevailing analysis of project failure found within the so-called Factors/Success School where analysis is orientated around "descriptive statistics on the criteria and factors of project success and failure" (Söderlund, 2011: 158): instead of asking how empirical analysis of project failure can provide us with "better" theories of project management (e.g. Cooke-Davies, 2002; Jha and lyer, 2007; Morris and Hough, 1987), we ask how might alternative empirical analysis of project failures, framed by different theoretical positions, help us conceptualize the limits of project management.

Our concern with the limits of project management is not intended as a critical trick or as conceptual legitimation of defective management; rather, we want to shed light on how a myriad of interwoven social, political, symbolic, economic and material, forces, enable, constrain and define project outcomes in ways that cannot be apprehended within existing 
research on project failure, and in particular that of the Factors School. In other words, we will examine the social contextualization of project management (Cicmil et al., 2009), and specifically project failure. This research will aid scholars and practitioners seeking to become more reflexive about the myriad influences not only on project outcomes (e.g. Cooke-Davies, 2002), but also on the more substantive question of how and why those outcomes are being defined and legitimated as failures or successes.

While the field of PM research is theoretically pluralist (Gauthier and Ika, 2012; Pellegrinelli, 2011), it is apparent that research into project failure/success is usually regarded as belonging to a narrowly managerialist, functionalist-positivist mode of enquiry, principally research within the Factors School. Söderlund (2011: 160) explains how Factors School analysis centres on the use of empirical data (usually cross-sectional surveys and more infrequently in-depth case studies) to produce descriptive statistics on the criteria and factors of project success and failure (see also the "Success School" of project management in Turner et al., 2013)). It is not our goal to dismiss this body of research - indeed, as we set out below it can inform our analysis of the limits of project management to apprehend and achieve project outcomes - yet we do believe that this research cannot, due in no small part to its location within a functionalist-positivist paradigm of knowledge, offer answers to the significance of such limitations. 
We develop our pluralist, "more-than-managerial", appreciation of project failure here through qualitative research in the UK construction industry. Construction is in an established projectbased industry that is suffused with discussions of performance failure, from the extraordinary: cost and time overruns in megaprojects such as the Channel Tunnel (Flyvbjerg, 2003); to the quotidian: the newly instigated "Dodgy Builder of the Year", award offered by the UK' Contract Journal (Contact, 2010). Since the 1980s, construction has witnessed the spread of standardized PM knowledge, methods and tools (e.g. Critical Path Analysis, PERT, TQM, BPR and lean) to enable better control and efficiency in the invariably unpredictable act of building (Applebaum, 1982; Green, 2003; 2006; Green et al. 2008; Styhre, 2006). The penetration of distinct PM knowledge beyond middle management at site-level remains debatable (Green, 2006). However, amongst most construction management (CM) researchers and senior managers, the development of generic PM tools grounded on a positivist-functionalist epistemology to understand and control the complex causes of unpredictability in building has become the mantra by which the future of the industry can be secured (Green, 2003, 2006; Green et al. 2008). Partly due to the spread of PM as the performance solution, from mega projects (Flyvbjerg, 2003) to home kitchen installation (Moben, 2010), failure increasingly becomes viewed in construction in terms of the failure of management to achieve expected outcomes. It frequently appears that project failures are project management failures: reproducing the managerialization of organization (Parker, 2002). 
This mutually reinforcing image of the construction industry as a low performing, yet highly performative, sector, is shared by both mainstream (Harris, 2006) and the far smaller number of critically-orientated studies of construction (Clarke, 2006; Clegg, 1975; Fletcher and Watson, 2007; Green, 2003; 2006; Green et al. 2008; Styhre, 2006). Conceivably, this highly performative image of construction contributes to the rather modest number of critical studies of construction work despite its sizeable socio-economic influence: perhaps this sector is simply too managerially performative for interesting critical study? By focussing on construction, we also follow Spicer et al. (2009) in challenging the notion that engagement with performativities is antithetical to the CMS agenda. In pursuing this "more than managerial" approach we also adopt a pluralist perspective, so as to generate new critical concepts by refusing to orientate studies of project failure around a managerial-positivist paradigm. However, in adopting this pluralist approach, we inevitably risk the charges of paradigm warriors defending the incommensurability thesis (Jackson and Carter, 1991); given this, before proceeding further, we will briefly revisit these heated debates to clarify why and how we are pursuing theoretical pluralism here.

\section{Theoretical pluralism revisited}

Since Burrell and Morgan's (1979) Sociological Paradigms and Organizational Analysis, theoretical pluralism as a research methodology has been criticized for inhibiting the potential for reflexive, non-performative, non-essentialist studies of management and organization 
(Alvesson et al. 2008; Deetz, 1996; Jackson and Carter, 1991; Parker and McHugh, 1991; Tadajewski, 2009). As a result, despite the general acceptance of the plurality of managerial rationalities (Hotho and Pollard, 2007), the plurality of modes of organization (Morgan, 1997), and the plurality of global politics (Dussell and Labarra-Collado, 2006), critical, but theoretically pluralistic work has been rare, either as an empirical (Hassard, 1991) or review-based (Davila and Oyon, 2007) contribution. And yet, there continues to be a steady, if diffuse, stream of calls for theoretical pluralism, as an aid to reflexive critical thinking across the social sciences (Bohman, 1999; Healy, 2003), as well business-related fields such as critical systems thinking (Bowers, 2011; Mingers and Brocklesby, 1997; Pollack, 2006), which continue to influence project management. By contrast, for many aligned with $\mathrm{CMS}$, the position on the theoretical fence appears full of splinters: by adjudicating amongst distinct theoretical approaches, authors construct a specious meta-theoretical view (see e.g. Mingers and Brocklesby, 1997) to claim underlying truths (Alvesson et al. 2008; Cox and Hassard, 2005; Parker and McHugh, 1991; Tadajewski, 2009), aid functionalist-positivist assimilation and orthodoxy (Burrell and Morgan, 1979; Jackson and Carter, 1991) or deny the politics and ethics of theory selection (Alvesson et al. 2008; Deetz, 1996; Tadajewski, 2009).

These are significant concerns, yet they are, we argue, a lesser threat to reflexivity and cosmopolitanism than the censoring of published dialogue between ostensibly distinct theoretical approaches (Weaver and Gioia, 1994: 576). Incommensurability can create caricatures, even "bogey-men" (Parker, 2002: 120), out of the approaches and concepts of 
mainstream management and organization studies colleagues (Parker, 2002: 115-127; see also Spicer et al., 2009), understating nuances within and connections across theoretical approaches (cf. Aitkin et al, 2007; Deetz, 1996; Ford et al. 2010). Relatively scarce critical engagement with project failure is, we argue, indicative of this problem. Perhaps the subject of project failure/success is inevitably too soiled with managerialist, positivist, or performative intent, for critical purchase. This lack of dialogue is problematic; after all surely it amplifies rather than resists, or subverts, the managerial translation of contemporary life (Parker, 2002). For some authors, the possibility of dialogue between different theoretical positions, especially 'critical' and 'mainstream' management studies, remains unachievable, given profound, and contradictory, ontological, epistemological, methodological, political, ethical and semantic differences (Jackson and Carter, 1991; Parker and McHugh, 1991). Others have protested that this charge is paradoxical: "how is it possible to understand others, even if only to delineate differences" (Weaver and Gioia, 1994: 572). The existence of theory textbooks, classes, informal discussions, interdisciplinarity and practitioner engagement, suggest that theoretical translation is far from unattainable or undesirable. Nevertheless any act of translation is always partial: both situated and incomplete (Haraway, 1991), replete with power effects (Carniawska, 1998; Tadajewski, 2009), and can, as such, operate as a form of repression (Burrell and Morgan, 1979; Jackson and Carter, 1991; Parker and McHugh, 1991). Yet, it is surely unfeasible to prohibit such acts as they are equally vital to academic learning, critique, creativity, collaboration, reflexivity and disciplinizaiton (Davila and Oyon, 2007; Kaghan and Phillips, 1998; Lewis and Keleman, 2002; Pollack, 2006; Weaver and Gioia, 1994; Willmott, 1993). 
Contra Scherer (1998: 155) we do not accept that theoretical pluralism, and translation, can only be justified if it resolves incommensurabilities. Borrowing Kaghan and Phillips's (1998: 207) allegory, too often, within management and organization studies, mainstream and critical traditions have been policed across rigid borders between a "no-man's-lands" rather than a porous border full of rich hybrid theories (see also Pollack, 2006: 386-387). Within the critical systems thinking field, Pollack (2006: 395) suggests a more pragmatic approach where paradigmatic incommensurabilities cannot be resolved, but neither are they absolute. Rather, they can present a map of possible compatibilities when addressing matters of practical, and we add political, concern (Pollack, 2006) or "problem situation[s]" (Bowers, 2011: 550). Our political concern here is to challenge the almost universal translation of project failure, under a positivist-functionalist epistemology wedded to a managerial performative intent, exemplified by the Factors School. Pluralism also usefully avoids fixing a critical project around a singular theoretical perspective which may inadvertently generate new orthodoxies and hegemonies (cf. Adler, 2008). One further caveat: we do not claim to provide a definitive survey of critical engagements with project failure; rather we hope to provide sufficient momentum, reflexivity and plurality to open up project failure, and similar emblems of managerialism in project management, for more critical analysis.

\section{Research approach}


Four theoretical orientations towards project failure, one seemingly orthodox and three arguably more "critical" are mobilized to inform an empirical analysis of project failure. First, positivist studies of critical failure factors (CFFs), secondly structural Marxist critique, thirdly interpretative narrative analysis, and fourthly actor-network theory (ANT) studies. The inclusion of positivist studies of CFFs may appear a somewhat incongruous choice for some, given the critical orientation of this paper, and the acquiescence between positivism and performative intent (Fournier and Grey, 2000). However, as will be shown, even positivist studies of the causes of project failure are suggestive of a critique of managerialism, and its reduction of organization to a product of management.

The first author of this paper undertook 25 semi-structured interviews with PM practitioners, and observed 10 project planning meetings across six construction projects between 2008 and 2010. These project-based studies were part of a sustained interaction with a construction general contractor, which included interviews, and more informal conversations, site visits and meetings, with senior head-office based employees including the director and senior manager of human resources, the group auditor and business process improvement manager. Practitioners interviewed on-site included project managers, site managers, health and safety officers, design managers, project planners and quantity surveyors. The projects were chosen by the company as representative of projects that had or may experience failure, however defined. Practitioners were asked to explain the course of events which had led the project to its current situation, and also their role in influencing these events. They were also asked more 
general questions about how they define project/project management "failure" and "success". For the purposes of producing this paper, the analysis of this data was conducted separately set against each theoretical approach. The analysis of empirical material is not intended to be balanced or consistent, as judged from some meta-paradigm (as in Mingers and Brocklesby, 1997), but is rather in keeping with the different onto-epistemological approaches.

\section{Critical Failure Factors: on the margins of managerialism}

When asked directly how they understood project failure all interviewees initially defined project failure with reference to the failure to achieve cost, time and quality targets. For example, one project manager explained:

If I took a very simplistic approach I would suggest that project failure would be not completing on time, not making the required profit margin and not to the desired quality, as simple as that.

(Project Manager, Project A)

Such responses ostensibly reproduce mainstream (i.e. positivist, functionalist and performative

- Cicmil et al. 2009: 86) understandings of PM. Namely, that a project is a temporary 
organization that is an efficient, purposeful and orderly system defined by performative managerial criteria; failure to achieve these targets results in a "failed project" which devalues corporate/personal worth. However, the same project manager then indicated that project failure can be far from an outcome of managerial (non)performance per se, when asked whether a project could achieve its expected outcomes but still, in some sense fail:

I think you could get it on time and it could make the required profit margin, it could be built at the right quality, but if the brief is not what the client wants that could be a failure couldn't it? If he doesn't know what it is supposed to do.

(Project Manager, Project A).

This modality of failure corresponds not to the performative disjuncture between the planned project and its outcome - the failure of management - but rather that a pre-defined criterion for success might not adequately capture a more emergent, or ambiguous, project vision from stakeholders (Kreiner and Frederiksen, 2007; Tryggestad et al., 2010). If we follow a positivistfunctionalist trajectory we might ask how we can efficiently identify, formalize and cost such an emergent project vision of success/failure, perhaps via improved stakeholder management methods (Cooke-Davies, 2002); in effect restoring management authority and control. Positivist research on generalized critical failure factors (CFFs) in the so-called Factors Schools of project management (Söderlund, 2011), also speaks to this point, suggesting how 
communication of project goals is a significant CFF. Other established CFFs in construction projects include, inter alia, strategic fit, buildability of design, communication, hostile socioeconomic conditions, client politics and trust (Jha and lyer, 2007; Morris and Hough, 1987). Many of the factors listed above are not usually captured by standardized "best practice" PM guides (e.g. PMBoK, 2004); rather they develop any discussion of project failure immediately beyond the control-based model of PM. For example, socio-economic conditions clearly play an important role in the ability of a project manager to complete a project, yet are of course outside the remit of project management. Similarly, the introduction of new building codes, planning and legal processes, changes in labour supply, procurement strategies, executive personnel changes, design amendments or material costs can have an important influence on a project throughout the life-cycle; whilst the availability of credit and capital can cause projects to be cancelled, mothballed or substantially revised.

CFFs enable us to reach an appreciation of the limits of managerial performative intent: suggesting a distinction between project failure and PM failure (Cooke-Davies, 2002; Munns and Bjeirmi, 1996), and even perhaps organization and management (Parker, 2002) - without recourse to a critique of the positivist (i.e. objective, causal) ontology and epistemology of most PM knowledge. Whilst these positivist studies no doubt aspire to a performative (and functionalist) managerial intent, by searching for causal explanations of failure amenable to managerial control, such research also suggests the limits of even the most effective manager to perform well in all projects. Positivism may remain a poor accomplice for reflexive critical 
project studies, not least due its inherent downplaying of the dialogic relationship between research subject and researcher. And yet, these generic CFFs are suggestive, even productive, of the vagaries and limitations of managerial knowledge, agency and performative intent. While it remains debatable how much impact positivist forms of PM knowledge have in practice (Crawford and Pollack, 2007); CFFs, and other positivist studies of project failure, provide a useful example of how positivist research into projects confronts not only comforts those looking for easy managerial receipts for project performance.

\section{The inevitability of failure: projects and capital accumulation}

As the above studies reveal, despite the emphasis on isolating projects from society within structured PM methodologies (Cicmil, 2009; Hodgson and Cicmil, 2007), which no doubt benefits the pernicious conflation of management and organization (Parker, 2002); projects remain legally, politically, culturally and perhaps above all economically related to society (Engwall, 2003; Hodgson and Cicmil, 2006). Throughout our fieldwork in construction we encountered the effects of the current global economic downturn. During 2008/09 the contractor made redundant about a third of its employees, and several board members left, including the CEO. One large urban development project in the North of England was put on hold after the property developer (and its funding bank) went into administration during late 2008. The contractor then had to seek alternative sources of funding, eventually becoming their own client on the project. These problems mirror headline statistics: in 2009, output in the UK 
construction industry fell $11 \%$; this translated into a record 163,000 redundancies of direct employees, or about $8 \%$ of the labour force (ONS, 2009). The dependence of the construction industry on the easy availability of credit heightens the exposure of the sector to economic crises. And yet, for some the economic downturn seemed partly beneficial: a project manager working on a private hospital project in London reported how he had benefited from the increased availability of labour, enabling his sub-contractors to source and retain labour at a lower cost. Whilst we might view economic issues, as simple beyond the remit of project managers, and thus project management research, analyses of project failures can provides a valuable exposition of the contradictions of capitalism, attempts to forestall such crises, and how the social consequences of both relate to project work.

Marx (1974) famously suggested that internal crises are endemic within capitalism, because it tends towards an over-accumulation of capital, relative to the potential of capitalists to find new sources of surplus value from labour. For example, from the mid-1960s the US-led economic model of rigid mass production and mass consumption (Fordism) created an excess of capital relative to new sources of surplus value: the immediate response was to attempt to devalue labour, equipment and capital (e.g. inflation, unemployment, writing off assets), the long-term response was a gradual shift from the late 1970s towards more flexible and mobile forms of capital accumulation, including the growth of more speculative financial and capital investments (for detailed analysis see Harvey, 1989: 125-146). Viewed through a radical Marxist perspective the much-cited inability of projects to fail to achieve expected time/cost/quality 
criteria (Cicmil, 2009: 84) is unsurprising given the crises tendencies within capitalism. The relentless quest for surplus value encourages more flexible and mobile, yet also speculative, complex, grandiose and risky, forms of accumulation, whether (sub-prime) mortgage-backed securities or ambitious urban development projects. Thus, the "projectification of society" (Lundin and Soderholm, 1998), and the spread of structured PM (Hodgson and Cicmil, 2006), can be read under structural Marxism as part of a general shift since the mid 1970s from Fordism (mass produced, mass consumer, Taylorist management) towards more flexible, risky and mobile, forms of capital accumulation: globalized and innovative labour processes, markets, products, highly differentiated patterns of consumption, de/re-skilling, new forms of production and de-centralized management (see Clegg, 1990; Harvey, 1989).

At first glance, construction seems to operate outside of any transition from rigidity to flexibility (being an established project-based, craft-based industry - Stinchcombe, 1959). Yet, as Styhre (2006) notes, across the globe construction management is increasingly being decentralized. Site managers are given more and more administrative responsibility, whilst being charged with ensuring greater innovation, efficiency and creativity (Green, 2006). PM appears to support moves towards creativity, flexibility and efficiency by decentralizing managerial control (Styhre, 2006). However, in practice PM systems often increase the amount of time spent completing paperwork to plan and monitor, rather than implement work (Applebaum, 1982; Green, 2006; Styhre, 2006), causing stress and fatigue, reducing the time for informal discussion, problem- 
solving and communication on-site, and perhaps risking more failures (Kreiner and Frederiksen, 2007). Project managers regularly lament the increasing administrative burden:

Yes I think there is a burden of procedure. When you look at everything, yes its great that we do the environment and its great that we do these audits, but then when you add that to everything else we do and suddenly the guys get find $40 \%$ of their time is spent on stuff that is not related to the job.

(Project Manager, Project B)

The project-based employees we interviewed often worked in excess of 60 hours per week, on projects distant from home, causing work/life balance difficulties. Most interviewees' described work as tough (though meaningful):

Its relentless, the pressure is immense, the hours are horrific. Everything about it is bloody hard work and awful and yet there is something about it. And it may be all of a sudden that elevation is built or that roof is on or whatever it is.

(Project Manager, Project A) 
You are going to be cold in the winter, you are boiling hot in the summer, in the spring you are soaking wet so you have got to like it. It's just building things, big toys for big boys! .. product is what you are measured against I suppose at the end of the day. When everybody walks into that place and they go wow. Its nice to have financial encouragements but at the end of the day that wow factor especially with something like this.

(Site Manager, Project A)

In the UK the influences on, and consequences of, construction failures, can be explained further by examining more specific structural changes in the labour market since the 1970s. In the wake of recessions during the 1970s and early 80s, the Conservative government encouraged deregulation, under the auspices of entrepreneurial culture, allowing construction contractors to cut their direct employed operatives in half between 1970 and 2003, as well as reducing administrative staff (Clarke, 2006: 248), creating "hollowed out firms" (Green et al., 2008: 431); changes which have increased sub-contracting, self-employment and the administrative workload for site managers. Yet, these shifts aid owners of capital by reducing fixed labour costs thus providing structural flexibility to "sit out" economic crises (Green et al., 2008: 431). Fragmentation also supports managers by inhibiting moves towards unionization, offloading the costs of training and other employment benefits, including limits on working hours, sick leave and regular holidays (Clarke, 2006; Dainty et al., 2007; Green, 2006; Green et al., 2008). Recession redundancies, caused partly by stalled or abandoned (i.e. failed) projects, 
have supported rather than reversed moves towards self-employment (ONS, 2009). These trends towards fragmentation increase the workload of site managers, and potentially reduce collaboration, motivation and communication, and no doubt further increase the likelihood of project failure, however defined. In other words, both the global and UK construction "fixes" for capitalist crises may reciprocate yet more project failures, compounding any structural necessity to fund evermore ambitious projects.

More worryingly, managerial focus on project failures actually serves to mystify such complexities. Zero-sum logics of project failure/success obscure the social relations of construction by, in Marxist parlance, fetishizing the exchange value (to the client) of the finished building. In our study we witnessed the prominence given, in project websites, brochures, posters, Gantt charts and hoardings, to the value of the finished building. The value of the construction team, as the site managers above testify, is to be judged against the exchange value of the building to achieve planned outcomes, incentivized in performance bonuses and penalty fees; viewed from a Marxist perspective this inculcates a false consciousness: the exchange value of the building is constituted by the labour power, and social relations, enabling its production not the other way around.

Marxist approaches can help understand how and why project failure is endemic, even (for some) beneficial, within modern societies driven by capitalist creative destruction. Thus Marxist approaches provide one means to examine the socio-political context of projects (Engwall, 
2003). Knights and Wilmott (1990) explain how "With the constant revolutionizing of production, a number of less efficient/flexible/fortunate capitalists are continuously shaken out of the market" (p6). Project failures indicate one aspect of the antagonism between labour and capital, a story told in construction through over-ambitious and speculative projects, lost profits and careers, stalled urban developments, cover-pricing, "bogus" self-employment, black-listing of unionized workers, stress, discrimination and poor training and safety: all of which may ultimately contribute towards low productivity (Clarke, 2006; Dainty et al., 2007). In the UK construction industry, the trend towards innovation and flexibility, evidenced by modularization, automation and prefabrication technologies, promises new sources of profit through increased efficiency. These technologies acquiesce with calls that CM must develop more rigorous, yet flexible, controls over labour processes; including project management (Green, 2006; Styhre, 2006). In this reading, construction frequently enacts a capitalistic mantra of discovering new sources of surplus value through technological innovation, whilst management augments the subdivision, deskilling and instrumentalization of labour (Braverman, 1974). Viewed through a Marxist-structural approach the ubiquity of project failure, as well as the march of projectification, and structured PM (e.g. PMBoK, 2004), evidences and deepens the degradation of work, and by extension inequalities between those who own labour and capitial.

\section{Narrating the self through project failure}


The elaboration of Marxist critique beyond structural economic forces, into questions of subjectivity, meaning and culture (Parker, 2002: 27-30) has helped some critical authors understand how relations of power and exploitation in organizations are often maintained through rather than against individual agency (Knights and Willmott, 1990; Wilmott, 1993). For example, the excerpts from practitioners in the previous section indicate how construction projects help to produce a hegemonically masculine (instrumentalist, competitive, masochistic, even dangerous) aesthetics of work (Gheradi and Nicolini, 2002) that is desirable for capitalist production.

These neo-Marxist perspectives, have however, downplayed Marx's (1974) original emphasis on crises and failures as a means to understand social relations. Fincham (2002) offers a rare study of how project failure is integral to understanding the consequences and transformation of managerial identities, interests and power. Fincham (2002), draws upon narrative approaches to organizations (Czarniawska, 1997), not to explain project failure, or its consequences but to understand what happens when projects are labeled as "failing" or "failed". Fincham (2002: 5-6) describes how we might see "failure" in a constructive rather than descriptive way: constructing managerial selves through complex events and shaping specific actions. Narratives of "failure" can be used to encourage change (Vaara, 2002), benefitting certain people and interests (Brown and Jones, 1998), and constitutive by and of emergent power relations over the direction and scope of a project. 
Some of strongest narratives of project failure we encountered concerned those that had experienced a change in project manager; interestingly half of the projects we visited had experienced a change of project manager at some stage; and one had experienced two changes of project manager. This is perhaps not surprising, as Fincham (2002) suggests: "By linking failure with some 'they' or some predefined 'other', actors distance themselves from failure at the same time as claiming an understanding of it" (p6). Vaara (2002: 218) similarly explains how narratives of (merger) failure are often linked to the 'Other', whilst successes are attributed to the Self. Given these interpretive theories of failure, we can see how project directors may seek to replace managers on failing projects, simply to create distance from impending failure, and link themselves to future success. Likewise replacement project managers will seek to objectively identity and explain failures, often through simplified "scapegoating" or "conspiracy theories" (Brown and Jones, 1998; Vaara, 2002), not simply because they are interested in its objective causes perhaps to facilitate organizational learning, but rather because it can provide a powerful means to legitimate and aggrandize their own future actions (Whittle et al. 2009: 438).

One project manager described, in interview, how he had replaced a previous project manager on a large urban regeneration project who apparently resigned due to ill-health. This project manager explained how the project had suffered significant delays in the past, and was categorized by the contractor as a failing project. The new project manager attributed these 
problems largely due to the wrong cultural attitudes amongst the management team, which he claimed was entirely due to the previous project manager:

When I first came down the team itself was very down, lacking direction, very disheartened. There was no communication, it was very much as you walk down the corridor all the doors were shut and people were kind of ... we didn't have this set up, it was another set up we had over there. Everybody kind of retreated to their own little domain and there was no interaction. So the first thing I did was to try to get the communication, to get people talking to one another and it was hard with this project manager that was there. He was very brash, very loud, it was his way and it was hard to try and bring the team together. We started to turn it round, we had a social evening and people started to come up to me and tell me what the problems were on the night out. It kind of all went back to one centre point which was this particular project manager. Things did start to change, he then went away sick, left on sick leave, and then the team started to bond and talk. You started to hear some laughter which was missing.

(Project Manager, Project C)

This reply evidences a three-fold process of "Othering" wherein the project manager glorifies and heroifies himself. Three key rhetorical devices appear significant: zero-sum thinking, use of 
(im)personal voice and the elision of complexity. First, zero-sum logics emphasize discontinuity ("there was no communication", "all the doors were shut", "no interaction"); it is, after all, unlikely that all doors on site were shut and there no interaction and communication before this project manager took over. Secondly, the project manager employs an impersonal voice when discussing the past, he does not, for example, say "this project manager shut the doors, or this project manager stopped communication". This impersonal tone partly serves to emphasize the matter of fact nature of his observations, and make them sound less like a personal attack, but it is also seems to resonate with the impersonal approach of the previous project manager. He then shifts to a personal voice, when discussing the period since he took over, to elevate his own contribution ("the first thing I did", "tell me what the problems were", "We started to turn it around", "the team start to bond and talk"). Thirdly, the project manager evades details of the sick leave of the previous project manager, he mentions the sick leave, but it appears un-important. Notwithstanding confidentiality concerns, the incidence of sick leave complicates "Othering", it opens the possibility of a rather less heroic, account of the transition; perhaps the previous project manager was overworked? Was he stressed or ill, how was this illness impacting on his work? Above all, it appears the new project manager did not simply replace the previous manager because he did not perform, as the narrative seems to suggest, but simply because he could not work. By not elaborating on this aspect of transition, even if only to acknowledge sympathy for his predecessor, or recognize the contingency of his appointment, the project manager passively legitimizes his own agency. 
By undertaking such close readings of how failure narratives are mobilized to legitimatize managerial identities and action, we can start to unpack how project managers aggrandize their own agency and competence through narratives of failure/success. New project managers we observed, regularly constructed their predecessors as "adversaries" (Vaara, 2002: 238) or "villains" (Whittle et al. 2009: 427-29) to heroically 'Other' themselves and their actions when speaking to other practitioners and researchers. In the projects we visited three had experienced a change of project manager, two of these experienced three changes of project manager. These narratives are not intrinsically problematic, and can serve an important role in binding together a team during a period of organizational change or uncertainty, for example during a change of project manager (cf. Vaara, 2002; Whittle et al. 2009). Yet, taken at face value they can lead to rather simplistic understanding of the complexities and pathdependencies of a project, including its antagonistic social relations. This approach can aid a Neo-Marxist perspective, by making a distinction between the real failure of projects driven by structural socio-economic crises, and the subjective evocation of "project failure" as a two-fold response to such crises. On the one hand labels of project failure/success appear an integral component of the project manager's identity work, evidencing a means through which practitioners self-discipline themselves to managerial imperatives (Andersson and Wicklegren, 2009). On the other hand, narratives of "project failure" obscure the social relations of construction, providing simplifying myths of heroes and villains (Alvesson and Berg, 1992: 8183; Whittle et al. 2009), through which to make sense of unpredictability and suppress other viewpoints (e.g. re/deskilling, stress, overly optimistic projects, vested interests etc) which could, if made more visible, mediate transformations of managerial/organizational power, 
identities and interests. In the next section we will consider one means of rendering some of these complexities more visible, and perhaps amenable to modification.

\section{Material (re)distributions of project failure}

ANT studies have illustrated the transformative role of nonhumans to the co-ordination of projects, and managerial power (Blackburn, 2002; Linde and Linderoth, 2006; Pollack et al., 2013), not least in the context of construction (Harty, 2005; Sage et al., 2010b; Tryggestad et al., 2010). Bruno Latour (2005: 88), one of the originators of ANT (along with John Law and Michel Callon), even heralds building sites as exemplars of ANT: the transformative symbiosis of humans and nonhumans (see Latour and Yaneva, 2008). During our field visits, various objects, including design drawings, critical path diagrams, even site office layout, provided constant transformations, interruptions, interpretations and limits to, managerial meanings and actions within and around projects.

Two of the authors of this paper visited a mix-use residential/retail project that was viewed across the company, and the in the local media, as shorthand for construction project failure, and a repertoire of narratives of what not to do. The senior design manager on the project translated failure in univocal terms: the project never could or would achieve its expected targets. Following the advice of Latour (2005: 55) to follow the associations of actors, but 
contra Fincham (2002), we followed this forensic (even quasi-positivist, Latour, 2005: 156) line of reasoning further and asked why the project had not achieved its targets. The design manager explained how the project had been beset by a lack of design information from the architect. The architects were not selected by the contractor, and they had never worked with each other before, but were instead novated to the contractor by the client, as this, along with most medium size construction projects in the UK, was a design and build (DB) project. The contractor had agreed to undertake the project given the overview plans from the architect and the tender offer (with performance targets); however the contractor might reasonably assume that the architect should work with them to develop detail on the drawings. Instead the design manager described how the architect would discuss updates and release information via emails and in meetings, but would not update the drawings. The drawings were evoked by the design manager as a key mediator in the building process and its failure:

The amount of meetings we had to have with the architect to establish what was needed. And what they tend to do is, which they shouldn't do but they do do a lot of architects, is you have these meetings and they don't follow it up by reflecting it on the drawings. They don't develop their drawings from the initial tender scheme, they tend to just cover it by metre blocks of various emails, yes we can change the partitions to such a spec, or this is the colour of the standing ceiling.

(Design Manager, Project D) 
Without updated drawings, the design manager was denied a key means to register the number of new actors, and mediators, involved in the updated construction process. Without drawings it is difficult to visualize what new building processes may be involved, as well as what materials, skills, equipment and legal and financial resources. The contractor eventually chose to employ their own architects to update the drawings; they intended to legally claim the costs of doing so back from the architects. The design manager explained how the lack of drawings quickly soured the relationship between the architect and the contractor, and caused substantial delays.

In this example we can see how objects are crucial in enabling the project to move forward and indeed to define what "moving forward" might actually mean, and how it can be measured. Drawings are a crucial actor, or obligatory passage point (Callon, 1986: 203), in the building process: without constantly updated visual information, site managers and sub-contractors cannot plan, co-ordinate, monitor or cost the tasks to be undertaken on-site. Instead operatives are perhaps given "hospital jobs": work which is outside of the espoused "critical path" of the project, increasing costs and slowing progress. In our example the architect appears to treat the drawing as a black-boxed intermediary that will bring about the construction of the building without further controversies or transformations. By contrast, the design manager views the drawings as fluid objects (de Laet and Mol, 2000), which will provoke constant reinterpretation as the building is constructed. In this case it appears that the design manager better appreciates the emergent role of the design drawings, whereby they must evolve alongside the 
building itself, even project goals might be transformed as the building is built (Tryggestad et al. 2010). The architectural firm, by contrast, seems content to be disconnected from these material complexities.

Some may extrapolate from this situation an opposition between the orderly disembodied nature of architecture and the messy emergent materialities of site work. Whilst, such generalizations might be accurate to some extent, especially given the long-standing separation of design and building processes (see Sage, 2012), various ANT orientated studies of design (Eisenstein and Whyte 2009; Latour and Yaneva, 2008; Yaneva, 2009) illustrate how architects are preoccupied with the relational and emergent aspects of design. Design drawings are more than simply information conduits or mirrors of the professional power of the architect, they provide an indeterminate epistemic object through which significant meanings and actions within the project can, and are, distributed, enacted and transformed (Eisenstein and Whyte 2009). The analytical distinction between actions and meanings seems less relevant to the practitioners involved, what is important are the capacities of actors (including drawings) to enter into the collectivity of building, or not. Across this example, the drawings are shown not to objectively cause project failure, but rather they help distribute responsibilities, identities and actions for defining, understanding and monitoring project "success" and "failure".

Design drawings are also involved in more subtle material relations which Law (2002: 102) has called "absent presences"; these are relations which are not explicitly discussed but continue to 
shape action and thought. A key absent presence to drawings is the formal contract: the architect commonly receives the majority of their fee upfront hence they are perhaps disincentivized from the outset to assist in the build phase. The materiality of the building site is another key absent presence in the design drawings (Latour and Yaneva, 2008: 84). Building plant, materials and labour are fairly immobile compared to design information - they require a large amount of energy (which translates as time and money) to render mobile. The lack of mobility on site can only be overcome by the rapid flow of design information, to minimize the costs of moving materials, labour and plant. Hence any intransigence of design information will require time and money to render the site more mobile to compensate. Despite the implicit political importance of drawings, when interviewed the design manager explicitly refused to discuss the contract, or project politics and financing, and saw his role as purely "technical" possibly reflecting pervasive disciplinary distinctions based on subject-object, humannonhuman, nature-culture dualisms (Law, 2006: 132-33). And yet, drawings are a highly politicized object through which the contract is translated and transformed. Whilst a building contract outlines broad legal responsibilities and can be used delimit "post hoc" agency and cognition, there are numerous artifacts of "ad hoc" agency and cognition in construction that through which a contract is translated and transformed.

Across this brief example, it is evident how design artifacts are crucial transformers of PM. They are significant in the planning, implementation and monitoring of work, as well as being a site of controversies, understandings of self-identity, and power effects. The material potential of 
design artifacts, including drawings, emails and CAD and their divergent capacities to circulate, transform, rescale, reduce, juxtapose information, radically alters the way agency and cognition is distributed in a project team. Frequently the design process is shaped by relations with various absent presences, from the cost of moving plant to the details of formal contracts, which, as the design manager evidences, are often difficult to make manifest, and thus understand, within the technical vocabulary of design. Whilst we might view objects as integrative intermediaries that align practitioners, they are frequently transformative mediators capable of unpredictably altering managerial agency, transforming cognition and creating emergent power effects. The transformative role of design artifacts not only indicates the limits of the influence of heroic management control but actually makes it possible to understand how control or management might take on a specific meaning through practice.

\section{Concluding comments}

In this paper we have developed (partial) translations of project failure across four different theoretical approaches: positivism, structural Marxism, interpretivism and ANT. Each approach offers theoretically different, yet perhaps pragmatically, even politically, related, critiques of the control-based, profit-seeking, instrumentalist managerialism that pervades much PM (Hodgson and Cicmil, 2006; Cicmil et al. 2009). While we do not presume that we can resolve incommensurate ontological, epistemological, methodological positions (contra Gioia and Pitre, 1990; Lewis and Grimes, 1999; Lewis and Keleman, 2002), it is striking how all of the 
approaches mobilized here offer politically compatible insights into how project failures necessarily develop critical concerns with consequences and transformations of managerial power, interests and identities. Perhaps what binds together these analyses is there engagement with the questions around the significance of limits to management to apprehend project failures, rather than the failure of management to avoid project failure. However, our analyses go further than merely rehearsing the established distinction between project failure and project management failure (Cooke-Davies, 2002).

Positivist studies of CFFs indicate how PM necessarily identifies its own limits, the boundaries along which the outcomes of the project are beyond management. Positivism is typically associated with a narrow performative managerialism (Fournier and Grey, 2000); yet the empirical drive of positivism necessarily also evokes the limitations and vagaries of managerial control and performative intent, especially when applied to diagnose management failures. During recent years, the socio-economic context of construction projects constituted a significant CFF. Marxist critique provides a historicist explanation of how project failure is an endemic, necessary, and escalating feature of late capitalism. The ubiquity, even increase, of project failures, evidences a greater antagonism between labour and capital: an increasingly significant component of a turn towards flexible accumulation as a fix for this crisis. Projects provide capitalists with a managerial device to exploit labour power to gain greater surplus value; whilst simultaneously effacing these exploitations by, in part, fetishsizing the exchange value of the completed project over the use value of labour power. Marxist critique suggests 
why the material lives of project workers have become degraded by being linked to the fortunes of the precarious "project fix" for modern capitalism.

Interpretive analysis of project failure (e.g. Brown and Jones, 1998; Fincham, 2002) helps us describe how project failure constitutes a narrative that legitimatizes managerial actions and meanings. Project managers were shown to deploy "project failure" to Other their predecessors, and, in the process, aggrandize their own heroic contribution to a project; downscaling organizations to the interests of management (Parker, 2002). Viewed in this way "failure" elides some of the complexities and consequences of managerial power and interests, as suggested across positivist, Marxist and ANT approaches. ANT studies suggest that managerial actions and meanings are distributed across transformative socio-material assemblages. Contra to interpretative approaches (Fincham, 2002), ANT explains how project failure is not simply a social construct but rather an effect of the (re)distributions of agency and cognition across various artifacts. Nonhumans are shown to not only influence the outcomes of projects, but also enact associations through which such outcomes can be understood as significant or not (see also Sage et al., 2013). ANT can reveal how seemingly mundane or technical objects, such as drawings have powerful, and unpredictable, effects on the capacities of managers to understand, prioritize and rework their own identities and interests, and those of others, within a project. 
All of these theoretical approaches, and no doubt many others (e.g. psychoanalysis, phenomenology, critical realism), can address project failures critically - that is, in ways that help project practitioners better contextualize the outcomes of their projects, and as said earlier, address the definition and legitimation of those outcomes. Perhaps these perspectives will provide some comfort to project practitioners, facing a body of project management knowledge and practice, which perhaps too infrequently reflects upon the profound experiences and effects associated with the limitations (rather than failure per se) of management. By juxtaposing these approaches and others in our research we might reflect on significant differences, paradoxes, as well as similarities, in the way each address, even construct, a seemingly similar phenomena: project failure.

Project failures often appear highly ambiguous, as they are viewed differently over time and space (Cicmil et al. 2009; Lindahl and Rehn, 2007). Academic research is not immune from such equivocality. Positivism describes project failure as a determinate object out there that can be apprehended, and predicted, objectively through generalized causal forces. Marxism (at least in its classic structural form) suggests project failure is produced by a concealed antagonism between labour and capital. For interpretivists, project failure is a symbolic social construction: a narrative which is materially embedded in organizations, but ultimately is driven by emergent socialized phenomena, such as concerns with managerial power, identities and interests. ANT suggests we recognize project failure as a socio-material phenomenon, but unlike positivism or structural-Marxism, it is not a determinate or objective phenomenon, because its meaning and 
agency is assembled from an emergent assemblage of symbolic and material relations, relations which can always be transformed. There are also broader paradoxes: whilst Marx famously resisted attempts to view humans as objects (Marx, 1974: 44-58); Latour asks we treat humans "as well as" (Latour, 2005: 255) nonhumans. Equally, positivist studies encourage a value-free study of knowledge, where the facts speak for themselves, whilst interpretive approaches, stress how objects of knowledge are always constructed by and of socialized relations.

In fleshing out this points of connection and contestation, our contribution here is modest: we have not sought to resolve, or overcome paradigmatic incommensurabilities through metaadjudication (contra Gauthier and Ika, 2012; Mingers and Brocklesby, 1997), but to reflexively flesh out a plurality of theoretical trajectories, that can be mobilized to help practitioners and scholars reflect upon social and political influences not only on project outcomes, but also the ways through which such outcomes are defined and legitimated. Of course, it is possible that reflexive practitioners may (re)deploy the concepts presented here to legitimate defective management, but so also is the possibility that they may help clients, stakeholders, end-users and project practitioners, to be more cautious, more hesitant, and hopefully more ethical, when giving or receiving interpretations of project "failure" (or "success"). Following Pollack (2006) we do not deny onto-epistemological incommensurability, but suggest different theoretical approaches can be minimally compatible when addressing such practical, and we add here political, matters of concern (see also Bowers, 2011). We advocate theoretical pluralism as a means of introducing plurality as a political intervention against functionalist- 
positivist/managerial orthodoxy, while recognizing the limitations of pluralism as a methodology to develop more substantive analysis (especially within the confines of a single research paper).

Indeed despite acknowledging incommensurabilities, we have identified some possibilities for partial translation (Haraway, 1991) between these theoretical approaches. For example, positivist studies revealing the importance of socio-economic contexts to projects might usefully inform Marxist critique as evidence of crises of late capitalism. Similarly, ANT scholars might translate positivistic insights about the determinate causes of failure, such as drawings, as a means to identify objects that actively influence how practitioners understand failure (and success). In both instances of partial translation we recognize a broader partiality: we the authors are politically and ethical partial by refusing to instrumentalize knowledge to a performative managerial intent. Yet unlike many critical studies we have focused upon exemplars of performativity - project failures - to illustrate how engagement with practitioner and mainstream concerns offer a rich vein of critique of managerial analysis of performativity, exemplified by the Factors School.

When specifying the CMS problematic over a decade ago, Fournier and Grey (2000: 12) recognized the critical purchase gained by studying what was being done in the name of managerial designations of performance, including presumably project failures, yet, perhaps fearing accusations of performative translation (Jackson and Carter, 1991), rather few critical 
studies have interrogated managerial designations of failure. We have addressed the wake of this lacuna in a field of management - construction project management - firmly orientated around issues of performance. We propose to critically-minded project scholars that practitioner concerns with failure (and success) in projects are not perhaps wholly removed from their own. Moreover, we also hope to persuade some mainstream project management scholars interested in issues of project performance, and experienced in functionalist-positivist approaches, that doing critical project studies does not mean abandoning your interests and expertise. Thus this paper is also an argument against unnecessary detachment and antagonism between "critical" and "mainstream" management communities (cf. Cicmil et al., 2009). The call for non-performative research encouraged by Fournier and Grey (2000), and the incommensurability thesis of Burrell and Morgan (1979), were seminal moments in the fortification of the CMS problematic against managerial orthodoxies, including the instrumentalization of scholarly knowledge to unquestioned managerial goals. However, if this armor is too eagerly polished it can equally provide a reflective surface where managerial orthodoxies rediscover their own images (Aitken et al., 2007; Spicer et al., 2009). The reflexive, denaturalizing imperative of CMS (Fournier and Grey, 2000), suggests that sometimes this armor must be creatively spoiled, pierced and distorted, even if we create monstrous hybrid theories: "hopeful monsters - as places where the necessary incompatibilities, inconsistencies and overlaps come gently and creatively together" (Law, 1991: 18).

\section{References}


Aitkin, I., Hassard, J., Cox, J, W., 2007. Excess and Mimesis in Organizational Theory:

Emancipation from Within?. Culture and Organization, 13(2), 145-156.

Alvesson, M., Berg, P, O., 1992. Corporate Culture and Organizational Symbolism. Walter de Gruyter: Berlin.

Alvesson, M., Hardy, C., Harley, B., 2008 Reflecting on Reflexivity: Reflexive Textual Practices in Organizational and Management Theory. Journal of Management Studies. 45(3), 480-501.

Andersson, T., Wicklegren, M., (2009) Who is colonizing whom? Intertwined identities in product development projects. Ephemera, 9(2), 168-181.

Applebaum, H, A., 1982. Construction Management: Traditional versus Bureaucratic Methods. Anthropological Quarterly, 55(4), 224-234.

Blackburn, S., 2002. The project manager and the project-network. International Journal of Project Management, 20, 199-204. 
Bohman, J., 1999. Theories, Practices, and Pluralism. Philosophy of the Social Sciences, 29(4), 459-480.

Braverman, H., 1974. Labour and monopoly capital: the Degradation of Work in the Twentieth Century. Monthly Review Press, New York.

Bresnen, M., 2007. Deconstructing partnering in project-based organization: Seven pillars, seven paradoxes and seven deadly sins, International Journal of Managing Projects in Business, $25,365-374$.

Bowers, T., 2011. Towards a Framework for Multiparadigm Methodologies, Systems Research and Behavioral Science, 28, 537-552.

Brown, A, D., Jones, M, R., 1998. Doomed to Failure: Narratives of Inevitability and Conspiracy in a Failed IS Project. Organization Studies, 19(1), 73-88.

Burrell, G., Morgan, G., 1979. Sociological Paradigms and Organizational Analysis. Ashgate, Aldershot. 
Callon, M., 1986. Some elements of a Sociology of Translation: Domestication of the Scallops and the Fishermen of St Brieuc Bay. In: Law, J. (Ed.) Power, action and belief: a new sociology of knowledge Routledge, London, pp.196-223.

Cicmil, S., Hodgson, D., Lindgren, M., Packendorff, J., 2009. Project management behind the façade. Ephemera, 9(2), 78-92.

Clarke, L., 2006. Valuing labour. Building Research and Information, 34(3), 246-256.

Clegg, S., 1975. Power, Domination and Rule: A Critical and Empirical Understanding of Power in Sociological Theory and Organizational Life, Routledge and Paul, London

Clegg, S., 1990. Modern Organizations: Organization Studies in the Postmodern World, Sage, London.

Clegg, S., Courpasson, D., 2004. Political Hybrids: Tocquevillean Views on Project Organizations, Journal of Management Studies, 41(4), 525-547. 
Contact (2010) The nominees for the Dodgy Builder of the Year award are... ,

http://www.contractjournal.com/blogs/the-foreman-blog/2008/09/the-nominees-for-thedodgy-bui.html

Accessed 12th March 2009.

Cooke-Davies, T., 2002. The "real" success factors on projects. International Journal of Project Management, 20, 185-190.

Cox, J, W., Hassard, J., 2005. Triangulation in Organizational Research: A Re-Presentation.

Organization, 12(1), 109-133.

Crawford, L. Pollack, J., 2007. How Generic are Project Management Knowledge and Practice', Project Management Journal, 38(1),87-96.

Czarniawska, B., 1997. Narrating the Organization. Chicago University Press, Chicago.

Dainty, A.R.J., Green, S.D., Bagilhole, B.M.,(Eds.) 2007. People and Culture in Construction: A Reader. Taylor and Francis, Oxford. 
Davila, T., Oyon, D., 2007, Cross-paradigm collabouration and the advancement of management accounting knowledge. Critical Perspectives on Accounting, 19, 887-893.

Deetz, S., 1996. Describing Differences in Approaches to Organizational Science: Rethinking Burrell and Morgan and Their Legacy. Organization Science, 7(2), 191-207.

de Laet, M., Mol., A., 2000. The Zimbabwe Bush Pump: Mechanics of a Fluid Technology. Social Studies of Science, 30(2), 225-263.

Dussell, E., Labarra-Collado, E., 2006. Globalization, Organization and the Ethics of Liberation. Organization. 13(4), 489-508.

Ewenstein, B., Whyte., J., 2009. Knowledge Practices in Design: The Role of Visual Representations as 'Epistemic Objects'. Organization Studies, 30(1), 7-30.

Engwall, M., 2003. No project is an island: linking projects to history and context, Research Policy, 32(5), 789-808.

Fincham, R., 2002. Narratives of Success and Failure in Systems Development. British Journal of Management, 13, 1-14. 
Fletcher, D., Watson., T., 2007. Voice, Silence and the Business of Construction: Loud and Quiet Voices in the Construction of Personal Organizational and Social Realities. Organization 14(2), 155-174.

Flyvbjerg, B., Bruzelius, N., Rothengatter, W.,2003. Megaprojects and Risk: An Anatomy of Ambition, Cambridge University Press, Cambridge.

Ford, J., Harding, N., Learmonth, M., 2010. Who is it That Would Make Business Schools More Critical? Critical Reflections on Critical Management Studies. British Journal of Management, 21, S71-S81.

Fournier, V., Grey, C., 2000. At the Critical Moment: Conditions and Prospects for Critical Management Studies. Human Relations, 53(1), 7-32.

Gauthier, J., Ika, L., 2012. Foundations of Project Management Research: An Explicit and SixFacet Ontological Framework. Project Management Journal, 43(5), 5-23. 
Gherardi, S., Nicolini, D., 2002, Learning the Trade: A Culture of Safety in Practice. Organization 9(2), 191-223.

Gioia, D, A., Pitre, E., 1990. Multiparadigm Perspectives on Theory Building. Academy of Management Review, 15(4), 584- 602.

Green, S, D., 2003. Re-engineering construction: going against the grain. Building Research and Information. 31(2). 97-106.

Green, S, D., 2006. The Management of Projects in the Construction Industry: Context, Discourse and Self-Identity., In: Hodgsdon, D. and Cicmil, S. (Eds.) Making Projects Critical. Basingstoke, Palgrave, pp. 29-50.

Green, S, D. , Harty, C., Elumualim, A, A., Larsen, G, D., and Kao, C, C., 2008. On the discourse of construction competitiveness. Building Research and Information, 36 (5), 426-435.

Harris, F., Mcaffer, R., Edum-Fotwe, F., 2006. Modern Construction Management, Blackwell, London. 
Harty, C., 2005. Innovation in construction: a sociology of technology approach. Building Research and Information. 33(6), 512-522.

Harvey, D., 1989. The Condition of Postmodernity. Blackwell, London.

Haraway, D., 1991. Simians, Cyborgs, and Women: The Reinvention of Nature. Free Association Books, London.

Hassard, J., 1991. Multiple Paradigms and Organizational Analysis: A Case Study. Organization Studies, 12(2), 275-299.

Healy, S., 2003. Epistemological Pluralism and the 'politics of choice'. Futures, 35: 689-701.

Hodgson, D., 2002. Disciplining the Professional: The Case of Project Management. Journal of Management Studies, 39(6), 803-821.

Hodgson, D., 2004. Project Work: The Legacy of Bureaucratic Control in the Post-Bureaucratic Organization. Organization, 11(1), 81-100. 
Hodgson, D., 2005. Putting on a Professional Performance': Performativity, Subversion and Project Management. Organization, 12(1), 51-68.

Hodgson, D., Cicmil, S., 2006. Making Project Critical. Palgrave, Basingstoke.

Hodgson, D., Cicmil, S., 2007. The other side of projects: the case for critical project studies. International Journal of Managing Projects in Business. 1(1), 142-152.

Hodgson, D., Cicmil, S., 2007. The Politics of Standards in Modern Management: Making 'The Project' a Reality. Journal of Management Studies 44(3), 431-450.

Hotho, S., Pollard, D., 2007, Management at Negotiation at the Interface: Moving Beyond the Critical-Practice Impasse. Organization, 14(4), 583-603.

Jackson, N., Carter P., 1991. In Defence of Paradigm Incommensurability, Organization Studies, 12(1), 109-127.

Jha, K. N., Iya, K, C., 2007. Commitment, coordination, competence and the iron triangle. International Journal of Project Management, 25, 527-540. 
Kaghan, W., Phillips, N., 1998. Building the Tower of Babel: Communities of Practice and Paradigmatic Pluralism in Organization Studies. Organization, 5(2), 191-216.

Knights, D., Willmott, H., 1990. (Eds.) Labour Process Theory. Macmillan Press: Basingstoke.

Kreiner, K., Frederiksen, M, L., 2007. The Architecture of Success and Failure in Construction, Centre for Management Studies of the Building Process, available at:

http://www.clibyg.org/dyn/files/knowledge_items/10file/The_Architecture_of_Success_in_Con struction.pdf

Accessed $10^{\text {th }}$ February 2010.

Latour, B., 2005. Reassembling the Social: An Introduction to Actor-Network Theory, Oxford: Oxford University Press.

Latour, B., Yaneva, A., 2008. “Give me a Gun and I will Make All Buildings Move": An ANT’s View of Architecture', In: R, Geiser (Ed.), Explorations in Architecture: Teaching, Design, Research. Birkhäuser, Basel, pp. 80-89. 
Law, J., 1991. Introduction: monsters, machines and sociotechnical relations, In: J. Law. (Ed.) A Sociology of Monsters: Essays on Power, Technology and Domination. Routledge, London, pp. 1-23.

Law, J., 2002. Aircraft Stories: Decentering the Object in Technoscience. Duke University Press, Durham, NC

Law, J., 2006. After Method: mess in social science research. Routledge: London.

Lewis, M, W., Grimes, A, J., 1999. 'Metatriangulation: building theory from multiple paradigms. Academy of Management Review. 24(4), 672-690

Lewis, M, W., Keleman, M, L., 2002. Multiparadigm inquiry: Exploring organizational pluralism and paradox. Human Relations, 55(2), 251-275.

Lindahl, M., Rehn, A., 2007. Towards a Theory of Project Failure. International Journal of Management Concepts and Philosophy, 2(3), 246-254. 
Linde, A., Linderoth, H, C, J., 2006. An Actor-Network Theory Perspective on IT Projects. In:

Hodgson, D., and Cicmil, S. (Eds..), Making Projects Critical, Palgrave McMillan. Basingstoke, Hampshire, pp. 155-170.

Lindgren, M., Packendorff, J., 2006. What's New in New Forms of Organizing? On the Construction of Gender in Project-Based Work. Journal of Management Studies, 43(4), 841-862.

Lindgren, M., Packendorff, J., 2007. Performing arts and the art of performing - on coconstruction of project work and professional identities in theatres. International Journal of Project Management, 25, 354-364.

Lundin, R., A. Söderholm., 1998. Conceptualizing a projectified society, in: Lundin, R., and Midler, C., (Eds.), Projects as Arenas for Renewal and Learning Processes., Kluwer: Boston., pp. 13-23,

Marx, K., 1974. Capital: Volume 1. J.M Dent and Sons, London

Mingers, J., Brocklesby, J., 1997. Multimethodology: Towards a Framework for Mixing Methodologies, Omega, 25, 489-509. 
Moben (2010) Why Choose Moben Kitchens, http://www.moben.co.uk/why-choose-mobenkitchens/

Accessed $10^{\text {th }}$ March 2010.

Morgan, G., 1997. Images of Organization, Sage, London.

Morris, P.W.G., Hough, G.H., 1987. The Anatomy of Major Projects: A Study of the Reality of Project Management. John Wiley, Chichester

Munns, A, K., Bjeirmi, B,F., 1996. The role of project management in achieving project success, International Journal of Project Management, 14(2), 81-87.

ONS, 2009, Construction Statistics Annual 2009. Office of National Statistics, Basingstoke

Parker, M., 2002. Against Management, Polity: Cambridge. 
Parker, M., McHugh, G., 1991. Five Texts in Search of an Author: A Response to John Hassard's 'Multiple Paradigms and Organizational Analysis'. Organization Studies, 12(3), 451-456.

Pellegrinelli, S., 2011. What is in a name: project or programme?. International Journal of Project Management, 29, 232-240.

PMBoK, 2004. A Guide to the Project Management Body of Knowledge. Project Management Institute, Newtown Square.

Pollack, J., 2006. Pyramids or Silos: Alternative Representations of the Systems Thinking Paradigms, Systems Practice and Action Research, 19, 383-398

Pollack, J., Costello, K., and Sankearan, S., 2013. Applying Actor-Network Theory as a sensemaking framework for complex organisational change programs. International Journal of Project Management, http://dx.doi.org/10.1016/j.ijproman.2012.12.007

Sage, D, J., Dainty, A, R, J., Brookes, N, J., 2010a. A consideration of reflexive practice in the critical projects movement, International Journal of Project Management, 28, 539-546. 
Sage, D, J., Dainty, A, R, J., Brookes, N, J., 2010b. 'Who Reads the Project File? : Exploring The Power Effects of Knowledge Tools in Construction Project Management'. Construction Management and Economics, 28(6), 629-640.

Sage, D., 2012. “Danger Building Site - Keep Out!?”: a critical agenda for geographical engagement with contemporary construction industries. Social and Cultural Geography, 14(2), 168-191.

Sage, D., Dainty, A., Brookes, N. (2013) Thinking the ontological politics of managerial and critical performativities: An examination of project failure, Scandanvian Journal of Management, 29(3),

Scherer, A, G., 1998. Pluralism and Incommensurability in Strategic Management and Organization Theory. Organization, 5(2), 147-168.

Söderlund, J., 2011. Pluralism in Project Management: Navigating the Crossroads of Specialization and Fragmentation. International Journal of Management Reviews, 13, 153-176.

Spicer, A. Alvesson, M. Kärreman, D., 2009. Critical Performativity: The Unfinished Business of Critical Management Studies, Human Relations, 62, 537-560 
Stinchcombe, A., 1959. Bureaucratic and Craft Administration of Production,.Administrative Science Quarterly, 4(2), 168-188.

Styhre, A., 2006. The bureacratization of the project manager function: The case of the construction industry. International Journal of Managing Projects in Business, 24, 271-276.

Tadajewski, M. ,2009. The Debate That Won't Die? Values Incommensurability, Antagonism and Theory Choice. Organization, 16 (4), 467-485.

Tryggestad, K., Georg, S., Hernes, T., 2010. Constructing Buildings and Design Ambitions. Construction Management and Economics, 28(4), 695-706.

Turner, R., Anbari, F., Bredillet, C. 2008. Perspectives on research in project: the nine schools, Global Business Perspectives, 1, 2-28.

Vaara, E., 2002. On the Discursive Construction of Success/Failure in Narratives of Post-merger Intergration. Organization Studies. 23(2), 211-248. 
Weaver, G, R., Gioia, D, A., 1994. Paradigms Lost: Incommensurability vs Structurationist Inquiry. Organization Studies, 15(4), 565-590.

Whittle, A., Mueller, F., Mangan, A., 2009. 'Storytelling and 'Character': Victims, Villains and Heroes in a Case of Technological Change. Organization, 16(3), 425-442.

Willmott, H., 1993. Breaking the Paradigm Mentality. Organization Studies, 14(5), 681-719.

Yaneva., A., 2009. The Making of a Building: A Pragmatist Approach to Architecture, Peter Lang, Oxford: 